\title{
Which is the most effective biomaterial in indirect pulp capping? 4- year comparative randomized clinical trial
}

\section{Purpose}

The aim of this study is to compare the clinical outcomes of Mineral Trioxide Aggregate (MTA) and calcium hydroxide pulp capping after complete caries removal.

\section{Materials and Methods}

In 73 regular patients ( 47 women, 26 men; age $20.65 \pm 3.02$ years), having at least one deep carious lesion was recruited. Following complete caries removal, the pulp was indirectly capped with either MTA $(n=51)$ or calcium hydroxide $(n=49)$, randomly. Final restoration with a resin-based composite in a single session was performed. Clinical parameters including pulp vitality, sensitivity to cold or heat stimulants, percussion tests and discomfort during chewing and color were recorded after 6 months, 1 year, 2-year, 3-year and 4-year. Data were analysed statistically $(p<0.05)$

\section{Results}

After 4-year, the survival rates were $86 \%$ (for MTA), and $82.9 \%$ (for calcium hydroxide). Totally, 8 teeth from calcium hydroxide group and 7 teeth from MTA group were endodontically treated. No significant difference was detected between the groups in terms of pulp vitality $(p=0.613)$. Grey discoloration rate was $63 \%$ in MTA group.

\section{Conclusion}

Both pulp-capping materials, MTA and calcium hydroxide showed similar clinically successful performance in terms of pulp vitality in the treatment of deep dentin caries lesions after 4- year.

Keywords: Mineral trioxide aggregate, calcium hydroxide, indirect pulp capping, complete caries excavation, randomised clinical trial

\section{Introduction}

The goal of indirect pulp capping treatment of the vital teeth must be the protection of tooth vitality by regenerating reparative dentin at the materio - pulpal complex, that works as a biological seal before causing to the need of more expensive and invasive treatment option such as root-canal treatment (1).

For the stimulation of the self-remineralizing properties of dentin, bacteriostatic and / or bactericidal and biocompatible agents can be applied on deep dentin neighbouring vital pulp before the placement of permanent restoration. Calcium hydroxide $\left(\mathrm{Ca}(\mathrm{OH})_{2}\right)$ is widely used in the treatment of deep caries lesions. It has a series of reparative properties arising from thermoelectric stimulus blockage, initial low-grade irritation of pulp tissue, and anorganic calcium ion precipitation, which are demonstrated to be associated with the differentiation of dental pulpal cells $(2,3)$. On the other hand, some disadvantages were reported such as gradual degradation, tunnel defects, an increased number of inflammatory cells and localized pulp necrosis, over time (4-7). Hence, the treatment outcomes

\author{
Uzay Koc Vural' ${ }^{1}$, \\ Arlin Kiremitci ${ }^{1}$ (D), \\ Saadet Gokalp ${ }^{1} \mathbb{D}$
}

ORCID IDs of the authors: U.K.V. 0000-0002-8764-2174; A.K. 0000-0003-0901-8365; S.G. 0000-0001-8562-2013

'Department of Restorative Dentistry, Faculty of Dentistry, Hacettepe University, Ankara, Turkey

Corresponding Author: Uzay Koc Vural

E-mail: uzay.koc@hacettepe.edu.tr

Received: 15 May 2021

Revised: 22 July 2021 Accepted: 8 August 2021

DOI: $10.26650 /$ eor.2022895748 
of calcium hydroxide pulp-capping can be considered as unpredictable since different success rates ranged between $13-96 \%$ were reported, previously (8-10).

Considering the disadvantages of calcium hydroxide, bioactive silicate cements, such as mineral trioxide aggregate (MTA) was introduced with many indications including treatment of deep caries lesions. Although, pulp exposure cannot be seen directly in the absence of bleeding, an unpredictable micro-level pulp damage may occur during deep dentin caries excavation.

MTA has been introduced as a successful pulp-capping material owing to its small sized particles providing tight barrier against the migration of microorganisms and high $\mathrm{pH}$ level leading minimal inflammatory reaction during healing. Besides, MTA can stimulate cell differentiation/activation, which may contribute to hard tissue matrix formation/ mineralization (11). Ford, et al. (12) investigated the MTA pulp-capping in monkey teeth and found that the clinical performance of MTA was higher than calcium hydroxide in terms of pulpal inflammation and dentin bridge formation. MTA showed better hard tissue formation and less pulpal inflammation compared to calcium hydroxide (13).

Deep caries lesions can be treated by complete, partial or stepwise caries excavation techniques. Complete caries excavation technique suggests to remove whole carious lesion from dentin at one appointment. In partial caries excavation technique, only the caries in peripheral areas is removed. Stepwise technique suggests the removal of whole deep caries lesion at several appointments gradually (14). In complete caries excavation technique, decayed dentin is fully removed followed by final restoration. Nowadays, although complete caries excavation or removal of whole carious dentin regarded as over-treatment, several surveys carried out in different countries indicated that approximately $70 \%$ of the responding dentists continue to use complete caries removal technique thinking complete caries removal has an increased pulp exposure risk but the fear about the progression of the carious lesion is eliminated $(1,15-25)$. Thus, the caries removal technique must be the technique of choice depending on the time, patient's attendance to the second appointment or specific requirements of the patients. In this study, complete caries removal technique was applied as it is mostly preferred by dental practitioners. There is a limited number of mid-term clinical trials comparing the clinical performance of MTA and calcium hydroxide after complete caries removal, which allows clear recommendations for daily dental practice. As the survival rates of the treated teeth tend to drop with time, short - term findings may overestimate the treatment outcome $(8,26)$. Therefore, the aim of this mid-term clinical study was to compare the outcomes of MTA and calcium hydroxide indirect pulp-capping regarding conservation of pulp vitality in a 4-year follow-up period. The tested null hypothesis was there would be no difference between the materials in terms of treatment outcome at 4year follow-up period.

\section{Materials and Methods}

\section{Ethical statement}

This article contains studies with human participants. The local ethical committee approved this prospective random- ized clinical trial and registered to clinicaltrials.gov. All procedures were performed in line with the ethical standards of the institutional / national research committee and with the 1964 Helsinki declaration and its later amendments or comparable ethical standards. Written consent of each participant was obtained after the study procedures clearly explained.

\section{Sample size calculation}

Before the recruitment, the $\mathrm{n}$ number was calculated using the G-power program. The parameters were as follows: Effect size $=0.4$, type I error $=0.05$, power $=0.85$, Df $=5$. Although obtained sample size was $n=90$, the $n$ number was increased to 100 , to considering possible drop-outs.

\section{Study participants}

The candidates, presented with at least 1 permanent premolar / molar tooth characterized by deep caries lesions without pulp exposure were recruited to study population.

\section{Inclusion and exclusion criteria}

The inclusion criteria were as follows: the teeth judged by the clinician that; removal of the deep caries lesion after direct complete caries excavation would not cause to exposure of the pulp (radiograph depth reaching 3/4 of the dentin), absence of any signs of irreversible pulpitis at radiographic examination, including widening of the periodontal ligament or absence of periapical lesions, absence of spontaneous and heavy pain, abscesses, or sinus tract, functional permanent posterior teeth, where the direct restoration is indicated and the teeth, positively responded to the electric pulp-testing and negatively responded to thermal-testing. Exclusion criteria were; two or more cuspal loss, caries beneath the gingival margin, spontaneous pain history, presence of any periapical pathology, immature teeth with open apex and pathologic mobility

A hundred and ten patients were assessed for eligibility. The radiographs were used to predict the distance between the caries and the pulp. Seventeen candidates refused to participate $(n=26), 9$ candidates with deep caries lesion had spontaneous pain history $(n=12), 11$ teeth with deep caries lesion were unrestorable without crown restoration $(n=14)$. Finally, 100 teeth in 73 patients, meeting the inclusion criteria were recruited.

\section{Study groups}

The recruited teeth were randomly assigned as MTA or calcium hydroxide groups. After complete caries removal, the control group received the calcium hydroxide (Dycal, Dentsply/Caulk, Dentsply International Inc, Milford, DE, USA) while the test group received MTA (Dentsply, Tulsa Dental, Johnson City, TN, USA) pulp-capping followed by final restoration in the same session in both groups.

\section{Randomization and blinding}

The randomization unit was the tooth. A simple randomization technique was used for the selection of pulp-cap- 
ping material. Blinding of patients was also possible. To avoid possible influence in the process, the clinician was not aware about the indirect capping material until randomization during removal of the carious lesion. If more than one case is included into the study in one patient, after allocation of the first tooth, the second case was always treated using other pulp-capping material. Thus, neither the investigators nor the participants were not aware which treatment was administered. Blinding at the follow-ups were not possible in all cases due to the grey discoloration of MTA over time.

\section{Calibration}

Only one researcher managed the operative procedures for standardization. Kappa statistics were performed to reveal inter / intra examiner agreement at follow-ups. Inter and intra examiner agreement in the detection of success or failure was determined as perfect $(k>0.98)$.

\section{Interventions}

Description of the materials were presented in Table 1. All teeth were treated under consistent, standardized conditions using a minimal invasive standardized operative intervention procedure. Single operator conducted clinical treatments to standardize the procedures. A local anaesthetic was administered before the operation procedure, if needed (severe sensitivity or pain during the preparation, rinsing, or drying and dental phobia). Carious lesion was revealed using sterile diamond burs at high-speed under copious water-cooling. Removal of superficial and soft dentin was started from lateral walls and dentino-enamel junction using a sterilized sharp and spoon-shaped hand excavator. Then, a slow-speed handpiece with sterilized stainless-steel burs were used to complete caries excavation. The cavities were rinsed with water and dried with mild water.

Hardness, color and the unique sound of the dentine while probing were used to assess the caries free diagnosis of the dentine. The isolation was achieved with a well-performing saliva ejector and cotton rolls. Subsequently, the teeth were then randomly divided into MTA or calcium hydroxide groups. The materials were applied according to the manufacturer's instructions. A detailed application procedure, the names, compositions and manufacturers of the materials used are presented in previous report of the present study (27).

Following pulp capping, a resin modified glass ionomer cement (RMGIC), (SDI, Riva Light Cure LC, Southern Dental Industries, Bayswater, Australia) was mixed and placed according to manufacturers' instructions. Then, an etch\&rinse adhesive (Prime and Bond NT, Dentsply DeTrey, Konstanz, Germany) was applied. The cavities were eventually restored with composite resin (Gradia Direct Posterior, GC, Tokyo, Japan) using incremental layering technique. Composite finishing burs, discs and rubber cones were used for finishing and polishing of the final restoration.

\section{Data collection}

Two calibrated and experienced researches other than the operator were trained to ensure standardization of the evaluating process at recalls. They collected the demographic and clinical data from the patients. Demographic data included age, gender and number of interfered teeth at pre-treatment time, while clinical data were collected before the intervention (baseline) and at 6- month, 1-year, 2-year, 3-year and 4-year follow ups, which included electric pulp testing (Kerr Vitality Scanner 2006, SybronEndo, Orange, CA, USA), thermal testing (air-water syringe) tactile tests (palpation and percussion), as well as the predictors of inflammation and self-reported patient history.

The treatment outcome was decided as "clinically successful" when the following criteria were met: positive answer to electric pulp testing, negative response to cold stimuli or triggered but not lingering by air-water shrinkage, no general pain, normal response to tactile tests or triggered pain not lingering, absence of abscess, sinus tract and non-physiological tooth mobility. In case of persistent severe pain, negative response to electric pulp testing or triggered pain by tactile or cold tests, the patient was referred for root canal treatment and the treatment outcome was considered to be "clinically unsuccessful". The presence of discoloration reflecting from under the restoration also recorded.

\section{Table 1. Description of the materials.}

\begin{tabular}{|c|c|c|}
\hline Material & Composition & Manufacturer \\
\hline Dycal $^{\circledR}$ & $\begin{array}{l}\text { Base paste: } \\
\text { 1,3-Butylene glycol disalicylate, Zinc } \\
\text { oxide, Calciumphosphate, Calcium } \\
\text { tungstate, Iron oxide pigments } \\
\text { Catalyst paste: } \\
\text { Calciumhydroxide, N-ethyl-o/p- } \\
\text { toluene sulfonamide, Zinc oxide, } \\
\text { Titanium dioxide, Zinc stearate, } \\
\text { Iron oxide pigments (dentine shade } \\
\text { only) }\end{array}$ & $\begin{array}{l}\text { Dentsply/ } \\
\text { Caulk, Dentsply } \\
\text { International } \\
\text { Inc, Milford, DE, } \\
\text { USA }\end{array}$ \\
\hline $\begin{array}{l}\text { ProRoot }^{\circledast} \\
\text { MTA }\end{array}$ & $\begin{array}{l}\text { Oxides: } \mathrm{Lime}(\mathrm{CaO}), \mathrm{Silica}\left(\mathrm{SiO}_{2}\right) \text {, } \\
\text { Aluminum oxide }\left(\mathrm{Al}_{2} \mathrm{O}_{3}\right) \text {, Ferric } \\
\text { oxide }\left(\mathrm{Fe}_{2} \mathrm{O}_{3}\right) \text {, and } \mathrm{Bismuth} \text { trioxide } \\
\text { Tricalcium aluminate, Tetracalcium } \\
\text { aluminoferrite, Tricalcium aluminate }\end{array}$ & $\begin{array}{l}\text { Dentsply } \\
\text { Tulsa Dental, } \\
\text { Johnson City, } \\
\text { TN, USA }\end{array}$ \\
\hline $\begin{array}{l}\text { Riva Light } \\
\text { Cure }\end{array}$ & $\begin{array}{l}\text { Compartment 1: Polyacrylic Acid, } \\
\text { Tartaric Acid, } \\
\text { 2-Hydroxyethyl Methacrylate, } \\
\text { Dimethacrylate Cross-linker, Acidic } \\
\text { Monomer } \\
\text { Compartment 2: } \\
\text { Fluoroaluminosilicate glass powder }\end{array}$ & $\begin{array}{l}\text { LC/Southern } \\
\text { Dental } \\
\text { Industries - } \\
\text { SDI, Bayswater, } \\
\text { Australia }\end{array}$ \\
\hline $\begin{array}{l}\text { Prime and } \\
\text { Bond NT }\end{array}$ & $\begin{array}{l}\text { Di and Trimethacrylate resins, } \\
\text { PENTA (dipentaerythritol penta } \\
\text { acrylate monophosphate), } \\
\text { Nanofillers - Amorphous Silicon } \\
\text { Dioxide, Photoinitiators, Stabilizers, } \\
\text { Cetylamine hydrofluoride, Acetone }\end{array}$ & $\begin{array}{l}\text { Dentsply } \\
\text { Detrey, } \\
\text { Konstanz, } \\
\text { Germany }\end{array}$ \\
\hline $\begin{array}{l}\text { Gradia } \\
\text { Direct } \\
\text { Posterior }\end{array}$ & $\begin{array}{l}\text { Methacrylate monomers, Silica, } \\
\text { Fluoro-Alumino-Silicate Glass, } \\
\text { Prepolymerised filler, Pigments, } \\
\text { Catalysts }\end{array}$ & $\begin{array}{l}\text { GC, Tokyo, } \\
\text { Japan }\end{array}$ \\
\hline
\end{tabular}




\section{Statistical analysis}

IBM SPSS package version 19 (IBM, Armonk, NY,USA) was used for statistical analysis. The data were analysed using descriptive statistics including standard error, min. max. and mean values. The Kaplan-Meier survival analysis was conducted to reveal the survival rate. The qualitative variables were compared using Pearson chi-square, Fisher exact and logrank statistics tests. $\mathrm{P}<0.05$ was determined as statistically significant.

\section{Results}

The study population consisted of 47 women (64.4\%) and 26 men (35.6\%). The mean age was $20.65 \pm 3.02$ for the calcium hydroxide group and $21.18 \pm 3.85$ years for the MTA group. The most commonly recorded preoperative tooth symptom was sensitivity to cold air. The patient characteristics, tooth distribution and preoperative symptoms observed are shown in Table 2 . The recall rate was $72.1 \%$ at 4- year post-treatment. One patient at 24 months, 8- at 36 months, 5- at 48 months did not attend to follow up. At 48 months, out of 100 analysed treatments, 14 teeth were lost to follow-up (6 Pertaining to MTA group, and 8 pertaining to calcium hydroxide group) (Figure 1). At 4-year, 15 teeth were treated endodontically due to the irreversible pulpitis (2- at six months, 3- at 1 year, 1- at 2-year, 6- at 3-year, 3- at 4year) (Figure 1). The Kaplan-Meier function allowed the analysis of the cumulative survival rate of the pulp at 48 months. This function revealed that the survival rate $82.9 \%$ for calcium hydroxide and, $86 \%$ for MTA after 48 months. Survival

Table 2. The patient characteristics, tooth distribution and preoperative symptoms. *Mineral trioxide aggregate

\begin{tabular}{|c|c|c|}
\hline & Calcium hydroxide & MTA* \\
\hline & N \% & $\mathbf{N} \%$ \\
\hline \multicolumn{3}{|l|}{ Sex } \\
\hline Female & $20(27.4)$ & $27(37.0)$ \\
\hline Male & $14(19.2)$ & $12(16.4)$ \\
\hline \multicolumn{3}{|l|}{ Age range } \\
\hline $18-20$ & $23(31.5)$ & 24 (32.9) \\
\hline $21-25$ & $8(11.0)$ & $9(12.3)$ \\
\hline $26-30$ & $3(4.1)$ & $6(8.2)$ \\
\hline \multicolumn{3}{|c|}{ Tooth distribution } \\
\hline Premolar & $23(23.0)$ & $15(15.0)$ \\
\hline Molar & $26(26.0)$ & $36(36.0)$ \\
\hline \multicolumn{3}{|c|}{ Arch distribution } \\
\hline Upper & $28(28.3)$ & $23(23.2)$ \\
\hline Lower & $20(20.2)$ & $28(28.3)$ \\
\hline \multicolumn{3}{|c|}{ Preoperative symptoms } \\
\hline Cold & $17(17.0)$ & $24(24.0)$ \\
\hline Heat & $6(6.0)$ & $16(16.0)$ \\
\hline Chewing & $4(4.0)$ & $7(7.0)$ \\
\hline Percussion & $10(10.0)$ & $16(16.0)$ \\
\hline
\end{tabular}

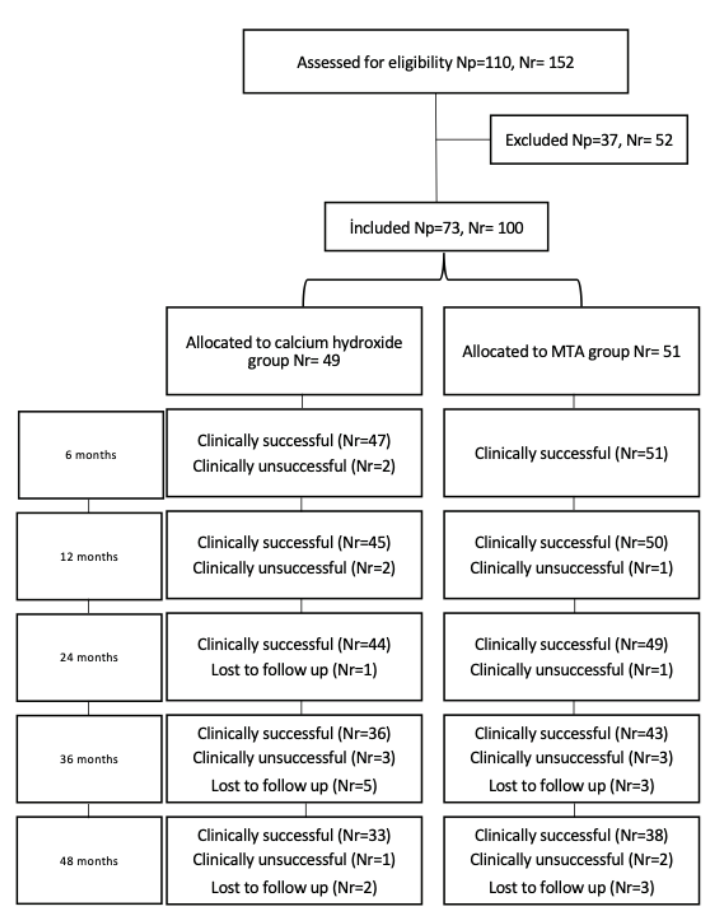

Figure 1. Flow diagram.

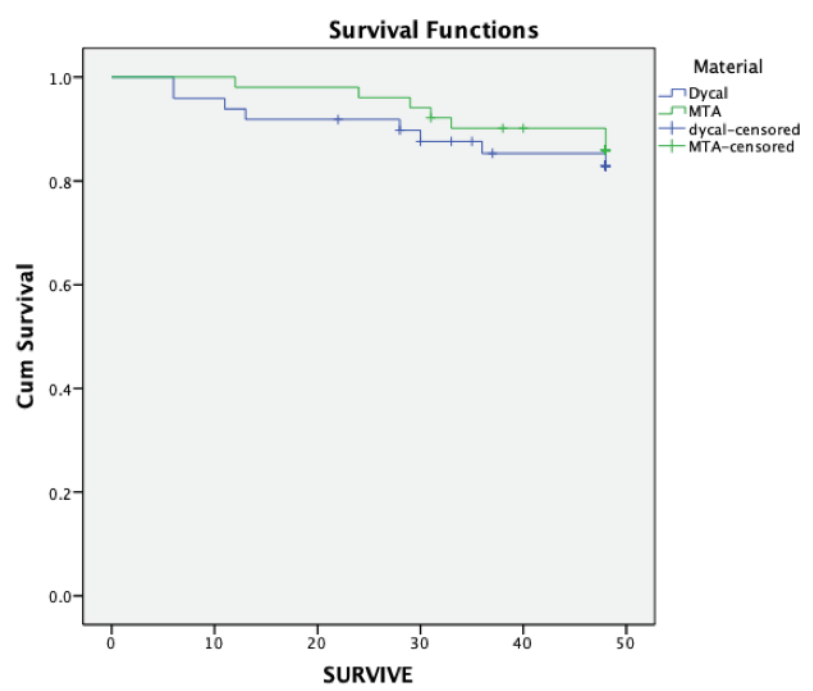

Figure 2. Survival after indirect pulp capping by materials (Kaplan-Meier curves).

Table 3. Distribution of symptoms at baseline, and 6, 12, 24, 36- and 48-months post-treatment. *Mineral trioxide aggregate

\begin{tabular}{|c|c|c|c|c|c|c|c|c|}
\hline & \multicolumn{4}{|c|}{ MTA* (n) } & \multicolumn{4}{|c|}{ Calcium hydroxide (n) } \\
\hline & 흥 & $\begin{array}{l}\text { 苋 } \\
\text { Ф் }\end{array}$ & & 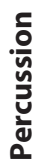 & 흥 & 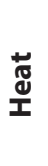 & 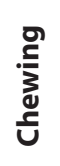 & 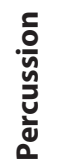 \\
\hline Baseline & 7 & 1 & - & 1 & 6 & 2 & 2 & 2 \\
\hline 6- mo & 5 & - & - & 2 & 2 & - & 1 & 2 \\
\hline 1 year & 3 & - & - & 1 & 7 & 1 & 1 & 1 \\
\hline 2- year & 2 & - & - & - & 3 & 1 & - & - \\
\hline 3- year & - & - & - & 1 & - & - & - & - \\
\hline 4- year & - & - & 1 & - & 1 & - & - & 1 \\
\hline
\end{tabular}


graphic showed that, the treatment success rate decreased over time (Figure 2). The longrank test showed no significant difference between the groups regarding the maintenance of pulp vitality at 4- year $(p=0.613)$.

The majority of the teeth included in the study were molars (62\%), whereas 38\% were premolars (Table 2). No significant relationship was found between upper and lower arches $(p=0.186)$ or premolar and molar teeth $(p=0.154)$ in terms of treatment outcome.

None of the teeth showed neither newly developed nor recurrent caries lesion. Only one tooth presented restoration failure at 4- year and received restoration repair. Since the tooth vitality was preserved, this tooth was not removed from the follow-ups. During the 4-year follow-up periods, symptoms were continued to reduce in both groups (Table 3 ).

At 4-year 1 tooth was symptomatic during the chewing in MTA group while 1-tooth were sensitive to cold-air and 1 tooth sensitive to percussion tests in calcium hydroxide group. Sixty-three percent of the MTA treated teeth showed grey discoloration.

\section{Discussion}

The null hypothesis was accepted as no difference was found between the indirect pulp capping materials in terms of success of the treatment outcome at 4-year follow-up period. An ideal pulp-capping material must have the ability to eliminate bacteria, to create an adequate seal and induce mineralization and normal root development (28). At present, despite their well-known drawbacks, calcium hydroxide and MTA are the materials of choice for direct or indirect pulp-capping treatments (28-33). Thus, these two materials were investigated in this randomized controlled study.

Studies showed that, MTA is one of the most investigated material as direct and indirect pulp-capping material $(7,34-$ 36). In direct pulp-capping studies, MTA showed superior results compared to calcium hydroxide (37-39). In histologic point of view, better results for MTA were reported compared to calcium hydroxide in terms of osteogenic, odontogenic and angiogenic effects, and inflammatory pulpal cell response $(40,41)$. Besides, in a recently released review article, it was reported that, MTA was found superior than calcium hydroxide for maintaining pulp vitality in direct pulp capping treatment at long-term (42). In terms of indirect pulp-capping of permanent teeth, no statistically significant difference between the materials were reported. The results of the present study are in line with the current literature as no significant differences were found between materials.

Marchi, et al. (43) conducted a 4- year follow-up study and reported $88 \%$ success rate for calcium hydroxide after indirect pulp-capping in primary teeth. The result of the current study showed that calcium hydroxide and MTA survival rates were $82.9 \%$ and $86 \%$, respectively in human posterior teeth at 4-year follow-up period in parallel with the current literature.

Although, MTA has a series of positive properties, its major disadvantage is an unsightly tooth-discoloration. Discoloration of the tooth after the MTA application can be very important especially in anterior region (44). In the present study $63 \%$ of the MTA group showed for grey discoloration, which was in consistent with the current reports (45-47). It is well known that to achieve a successful restoration at long- term relies on durable marginal integrity of the restoration (48). Leakage and bacterial migration from the restoration interface can cause a series of problem such as post-operative hypersensitivity, secondary caries and eventually failure of the restoration (49). In the present study building a wellsealed restoration was the main goal at every stage of the study. Therefore, less clinical symptoms and no secondary caries development during the course of the study was not surprising. Slight tooth sensitivity recorded in a few patients might be related with the preoperative condition of the pulp.

One of the limitations of this study was that blinding at the follow-ups. Some MTA treated cases showed grey discoloration, which makes the blinding impossible. Another limitation is study design. Present study planned as randomized only since to find a patient having at least two deep dentin caries lesions, meeting the inclusion criteria is very difficult. This specific study group did not allow to conduct the study in split-mouth study design. Thus, future studies must be designed considering these limitations.

\section{Conclusion}

Indirect pulp-capping with MTA was found clinically more successful than calcium hydroxide at 4- year post-treatment in the treatment of deep caries lesions. However, discoloration risk of MTA treated teeth must be taken into consideration. Prospective clinical trials comparing different indirect pulp capping materials in mid-term and long-term are needed.

Türkçe Özet: Indirekt pulpa kaplamasında en etkili biyomateryal hangisidir? 4 yıllık karşılaştırmalı randomize bir klinik çalışma. Amaç: $\mathrm{Bu}$ çalışmanın amacı, total çürük ekskavasyonu sonrası Mineral Trioksit Agregat (MTA) ve kalsiyum hidroksit pulpa kaplamasının klinik sonuçlarını karşılaştırmaktır. Gereç ve Yöntem: Çalışmaya en az bir derin çürük lezyonu olan 73 hasta (26 erkek; 47 kadın; ortalama yaş $20,65 \pm 3,02)$ dahil edildi. Total çürük ekskavasyonu sonrası, MTA( $n=51)$ veya kalsiyum hidroksit $(n=49)$ materyallerinden biri ile indirek pulpa kaplaması ve takiben tek seansta rezin bazlı bir kompozit ile daimi restorasyon yapıldı. Vitalite, soğuk veya sıcak uyaranlara duyarlılık, perküsyon testleri, çiğneme esnasında rahatsızlık ve renk gibi klinik parametreler 6 ay, 1 yıl, 2 yıl, 3 yıl ve 4 yıl kontrollerinde kaydedildi. Veriler istatistiksel olarak analiz edildi $(p<0.05)$. Bulgular: 4 yılda ağızda kalma oranları MTA için \%86 ve kalsiyum hidroksit için \%82.9 bulundu. Kalsiyum hidroksit grubundan 8, MTA grubundan 7 dişe kök-kanal tedavisi uygulandı. Pulpa vitalitesi açısından gruplar arasında anlamlı bir fark bulunmadı ( $p=0,613$ ). MTA grubunda gri renklenme oranı $\% 63$ bulundu. Sonuç: 4 yılda, derin dentin çürüğü lezyonlarının tedavisinde kullanılan MTA ve kalsiyum hidroksit materyalleri, pulpa vitalitesi açısından benzer klinik performans göstermiştir. Anahtar kelimeler: Mineral trioksit agregat, kalsiyum hidroksit, indirek pulpa kaplaması, total çürük ekskavasyonu, randomize klinik çalışma.

Ethics Committee Approval: The local ethical committee approved this prospective randomized clinical trial.

Informed Consent: Participants provided informed constent.

Peer-review: Externally peer-reviewed.

Author contributions: UKV, AK, SG participated in designing the study. UKV, AK, SG participated in generating the data for the study. UKV, AK, SG participated in gathering the data for the study. UKV, AK, SG participated in the analysis of the data. UKV wrote the majority of the original draft of the paper. UKV, SG participated in writing 
the paper. UKV, AK, SG have had access to all of the raw data of the study. UKV, AK, SG have reviewed the pertinent raw data on which the results and conclusions of this study are based. UKV, AK, SG have approved the final version of this paper. UKV, AK, SG guarantee that all individuals who meet the Journal's authorship criteria are included as authors of this paper.

Conflict of Interest: The authors declared no conflict of interest.

Financial Disclosure: This study was supported by Hacettepe University Scientific Research Projects Coordination Unit.

\section{References}

1. Schwendicke F. Contemporary concepts in carious tissue removal: A review. J Esthet Restor Dent 2017;29:403-8. [CrossRef]

2. Seux D, Couble ML, Hartmann DJ, Gauthier JP, Magloire H. Odontoblast-like cytodifferentiation of human dental pulp cells in vitro in the presence of a calcium hydroxide-containing cement. Arch Oral Biol 1991;36:117-28. [CrossRef]

3. Tziafas D, Pantelidou O, Alvanou A, Belibasakis G, Papadimitriou S. The dentinogenic effect of mineral trioxide aggregate (MTA) in short-term capping experiments. Int Endod J 2002;35:24554. [CrossRef]

4. D'Arcangelo C, Di Nardo-Di Maio F, Patrono C, Caputi S. NOS evaluations in human dental pulp-capping with MTA and calcium-hydroxide. Int J Immunopathol Pharmacol 2007;20:2732. [CrossRef]

5. Asgary S, Eghbal MJ, Parirokh M, Ghanavati F, Rahimi H. A comparative study of histologic response to different pulp capping materials and a novel endodontic cement. Oral Surg Oral Med Oral Pathol Oral Radiol Endod 2008;106:609-14. [CrossRef]

6. Nair PN, Duncan HF, Pitt Ford TR, Luder HU. Histological, ultrastructural and quantitative investigations on the response of healthy human pulps to experimental capping with Mineral Trioxide Aggregate: a randomized controlled trial. 2008. Int Endod J 2009;42:422-44. [CrossRef]

7. Aeinehchi M, Eslami B, Ghanbariha M, Saffar AS. Mineral trioxide aggregate (MTA) and calcium hydroxide as pulp-capping agents in human teeth: a preliminary report. Int Endod J 2003;36:22531. [CrossRef]

8. Barthel CR, Rosenkranz B, Leuenberg A, Roulet JF. Pulp capping of carious exposures: treatment outcome after 5 and 10 years: a retrospective study. J Endod 2000;26:525-8. [CrossRef]

9. Cvek M. A clinical report on partial pulpotomy and capping with calcium hydroxide in permanent incisors with complicated crown fracture. J Endod 1978;4:232-7. [CrossRef]

10. Mente J, Geletneky B, Ohle M, et al. Mineral trioxide aggregate or calcium hydroxide direct pulp capping: an analysis of the clinical treatment outcome. J Endod 2010;36:806-13. [CrossRef]

11. Okiji T, Yoshiba K. Reparative dentinogenesis induced by mineral trioxide aggregate: a review from the biological and physicochemical points of view. Int J Dent 2009(16878728):464280. [CrossRef]

12. Ford TR, Torabinejad M, Abedi HR, Bakland LK, Kariyawasam SP. Using mineral trioxide aggregate as a pulp-capping material. J Am Dent Assoc 1996;127:1491-4. [CrossRef]

13. Min KS, Kim HI, Park HJ, Pi SH, Hong CU, Kim EC. Human pulp cells response to Portland cement in vitro. J Endod 2007;33:1636. [CrossRef]

14. Ricketts D. Management of the deep carious lesion and the vital pulp dentine complex. Br Dent J 2001;191:606-10. [CrossRef]

15. Schwendicke F, Frencken JE, Bjorndal L, et al. Managing Carious Lesions: Consensus Recommendations on Carious Tissue Removal. Adv Dent Res 2016;28:58-67. [CrossRef]

16. Innes NP, Frencken JE, Bjorndal $L$, et al. Managing Carious Lesions: Consensus Recommendations on Terminology. Adv Dent Res 2016;28:49-57. [CrossRef]
17. Bjorndal L, Reit C, Bruun G, et al. Treatment of deep caries lesions in adults: randomized clinical trials comparing stepwise vs. direct complete excavation, and direct pulp capping vs. partial pulpotomy. Eur J Oral Sci 2010;118:290-7. [CrossRef]

18. Crespo-Gallardo I, Martin-Gonzalez J, Jimenez-Sanchez MC, Cabanillas-Balsera D, Sanchez-Dominguez B, Segura-Egea JJ. Dentist $s$ knowledge, attitudes and determining factors of the conservative approach in teeth with reversible pulpitis and deep caries lesions. J Clin Exp Dent 2018;10:1205-15. [CrossRef]

19. Koopaeei MM, Inglehart MR, McDonald N, Fontana M. General dentists', pediatric dentists, and endodontists' diagnostic assessment and treatment strategies for deep carious lesions: A comparative analysis. J Am Dent Assoc 2017;148:64-74. [CrossRef]

20. Schwendicke F, Meyer-Lueckel H, Dorfer C, Paris S. Attitudes and behaviour regarding deep dentin caries removal: a survey among German dentists. Caries Res 2013;47:566-73. [CrossRef]

21. Stangvaltaite $L$, Kundzina R, Eriksen HM, Kerosuo E. Treatment preferences of deep carious lesions in mature teeth: Questionnaire study among dentists in Northern Norway. Acta Odontol Scand 2013;71:1532-7. [CrossRef]

22. Alnahwi TH, Alhamad M, Majeed A, Nazir MA. Management preferences of deep caries in permanent teeth among dentists in Saudi Arabia. Eur J Dent 2018;12:300-4. [CrossRef]

23. Smail-Faugeron V, Porot A, Muller-Bolla M, Courson F. Indirect pulp capping versus pulpotomy for treating deep carious lesions approaching the pulp in primary teeth: a systematic review. Eur J Paediatr Dent 2016;17:107-12.

24. Weber CM, Alves LS, Maltz M. Treatment decisions for deep carious lesions in the Public Health Service in Southern Brazil. J Public Health Dent 2011;71:265-70. [CrossRef]

25. Oen KT, Thompson VP, Vena D, et al. Attitudes and expectations of treating deep caries: a PEARL Network survey. Gen Dent 2007;55:197-203.

26. Maltz M, Alves LS, Jardim JJ, Moura Mdos S, de Oliveira EF. Incomplete caries removal in deep lesions: a 10-year prospective study. Am J Dent 2011;24:211-4.

27. Koc Vural U, Kiremitci A, Gokalp S. Randomized Clinical Trial to Evaluate MTA Indirect Pulp Capping in Deep Caries Lesions After 24-Months. Oper Dent 2017;42:470-7. [CrossRef]

28. Witherspoon DE. Vital pulp therapy with new materials: new directions and treatment perspectives--permanent teeth. Pediatr Dent 2008;30:220-4. [CrossRef]

29. Schuurs AH, Gruythuysen RJ, Wesselink PR. Pulp capping with adhesive resin-based composite vs. calcium hydroxide: a review. Endod Dent Traumatol 2000;16:240-50. [CrossRef]

30. Accorinte Mde L, Holland R, Reis A, et al. Evaluation of mineral trioxide aggregate and calcium hydroxide cement as pulpcapping agents in human teeth. J Endod. 2008;34:1-6. [CrossRef]

31. Chisini LA, Conde MC, Correa MB, et al. Vital Pulp Therapies in Clinical Practice: Findings from a Survey with Dentist in Southern Brazil. Braz Dent J 2015;26:566-71. [CrossRef]

32. Witherspoon DE, Small JC, Harris GZ. Mineral trioxide aggregate pulpotomies: a case series outcomes assessment. J Am Dent Assoc 2006;137:610-18. [CrossRef]

33. Sawicki L, Pameijer CH, Emerich K, Adamowicz-Klepalska B. Histological evaluation of mineral trioxide aggregate and calcium hydroxide in direct pulp capping of human immature permanent teeth. Am J Dent 2008;21:262-6.

34. Akhlaghi N, Khademi A. Outcomes of vital pulp therapy in permanent teeth with different medicaments based on review of the literature. Dent Res J (Isfahan) 2015;12:406-17. [CrossRef]

35. Smail-Faugeron V, Glenny AM, Courson F, Durieux P, Muller-Bolla $M$, Fron Chabouis H. Pulp treatment for extensive decay in primary teeth. Cochrane Database Syst Rev 2018;5:CD003220. [CrossRef]

36. Tran XV, Salehi H, Truong MT, et al. Reparative Mineralized Tissue Characterization after Direct Pulp Capping with Calcium-SilicateBased Cements. Materials (Basel) 2019;12: 2102. [CrossRef]

37. Bogen G, Kim JS, Bakland LK. Direct pulp capping with mineral trioxide aggregate: an observational study. J Am Dent Assoc 2008;139:305-15. [CrossRef] 
38. Mente J, Hufnagel $\mathrm{S}$, Leo $\mathrm{M}$, et al. Treatment outcome of mineral trioxide aggregate or calcium hydroxide direct pulp capping: long-term results. J Endod 2014;40:1746-51. [CrossRef]

39. Hilton TJ, Ferracane JL, Mancl L, Northwest Practice-based Research Collaborative in Evidence-based D. Comparison of $\mathrm{CaOH}$ with MTA for direct pulp capping: a PBRN randomized clinical trial. J Dent Res 2013;92:16-22. [CrossRef]

40. Youssef AR, Emara R, Taher MM, et al. Effects of mineral trioxide aggregate, calcium hydroxide, biodentine and Emdogain on osteogenesis, Odontogenesis, angiogenesis and cell viability of dental pulp stem cells. BMC Oral Health 2019;19:133. [CrossRef]

41. Parolia A, Kundabala M, Rao NN, et al. A comparative histological analysis of human pulp following direct pulp capping with Propolis, mineral trioxide aggregate and Dycal. Aust Dent J 2010;55:59-64. [CrossRef]

42. Zhu C, Ju B, Ni R. Clinical outcome of direct pulp capping with MTA or calcium hydroxide: a systematic review and metaanalysis. Int J Clin Exp Med 2015;8:17055-60.

43. Marchi JJ, de Araujo FB, Froner AM, Straffon LH, Nor JE. Indirect pulp capping in the primary dentition: a 4 year follow-up study. J Clin Pediatr Dent 2006;31:68-71. [CrossRef]

44. Mozynska J, Metlerski M, Lipski M, Nowicka A. Tooth Discoloration Induced by Different Calcium Silicate-based
Cements: A Systematic Review of In Vitro Studies. J Endod 2017;43:1593-601. [CrossRef]

45. Alsubait S, Al-Haidar S, Al-Sharyan N. A Comparison of the Discoloration Potential for EndoSequence Bioceramic Root Repair Material Fast Set Putty and ProRoot MTA in Human Teeth: An In Vitro Study. J Esthet Restor Dent 2017;29:59-67. [CrossRef]

46. Marciano MA, Duarte MA, Camilleri J. Dental discoloration caused by bismuth oxide in MTA in the presence of sodium hypochlorite. Clin Oral Investig 2015;19:2201-9. [CrossRef]

47. Adl A, Javanmardi S, Abbaszadegan A. Assessment of tooth discoloration induced by biodentine and white mineral trioxide aggregate in the presence of blood. J Conserv Dent 2019;22:164-8. [CrossRef]

48. Savadi Oskoee S, Bahari M, Jafari Navimipour E, Ajami AA, Ghiasvand N, Savadi Oskoee A. Factors affecting marginal integrity of class II bulk-fill composite resin restorations. J Dent Res Dent Clin Dent Prospects 2017;11:101-9. [CrossRef]

49. Zhang C, Yang B. Long-term marginal adaptation and nanoleakage of class $V$ cavity restored with organic filler filled 4-META/MMA-TBB resin. J Biomed Mater Res B Appl Biomater 2019;107:2050-6. 